"His work gave him a lot of spirit. His commitment to research and writing enabled him to fight the disease as long as he did, " according to his wife, Ingrid Creppel, who is working on her doctoral dissertation in political philosophy for the University of Chicago.

$\mathrm{He}$ also is survived by his parents, Fanny and Yehoshua Hadari, of Tel Aviv, Israel, and a sister, Liora Youngman, of Jerusalem.

Services were held Wednesday, July 6, at the Holon Cemetery in Tel Aviv.

Born September 15, 1955, in Tel Aviv, Hadari graduated cum laude from Tel Aviv University in 1979, then earned his M.A. at Princeton in 1981 and his Ph.D. there in 1983.

He was a teaching assistant at both universities before being named an assistant professor at Wake Forest University, where he taught before coming to Stanford last September.

He taught a seminar in "Equality and Liberty" and courses in "Rousseau and His Readers" and "Reading Political Theory."

He was fluent in English, French, and Hebrew and also was a jazz pianist.

The family prefers memorial contributions to the I Have a Dream Foundation/ REFAC, 100 East 42nd Street, 3rd Floor, New York, NY 10017.

Reprinted from Campus Report, June 29, 1988 , p. 3. Stanford University.

\section{Charles H. Levine}

Charles H. Levine, Distinguished Professor of Government and Public Administration at The American University, died suddenly of a heart attack at his home in Chevy Chase, Maryland, on September 23, at the age of 49 .

Charles Levine, Charlie to his friends, combined the qualities of distinguished scholar, teacher, public servant, generous and reliable friend, sportsman, professional colleague, and above all a loving husband and father.

Given the short span of his professional life, his contributions to public administration and political science were prodigious.
In less than two short decades, Charlie became one of the most prolific scholars in the field of public administration having published nine books and over sixty scholarly articles and chapters with major contributions on topics ranging from civil service reform, cutback management, human resource management, urban politics, to the politics of racial conflict and poverty. He combined the best of political science with public administration and business management working with Charles $\mathrm{S}$. Hyneman, York Willbern, James Thompson, Fred Diamant while earning an M.B.A., M.P.A., and Ph.D. from Indiana University. Having published several scholarly articles before leaving graduate school, he quickly launched his career with the publication of Racial Conflict and the American Mayor: Power, Polarization, and Performance in 1974.

At the time of his death, Charlie had just finished a joint project, Public Administration: Challenge, Choices, and Consequences with B. Guy Peters and Frank J. Thompson. His other major works include Expertise and Democratic Decision Making with Peter Benda; The Unfinished Agenda for Civil Service Reform; The Politics of Retrenchment: How Local Governments Manoge Fiscal Stress with Irene S. Rubin and George G. Wolohojian; Fiscal Stress and Public Policy with Irene S. Rubin; Managing Fiscal Stress; Urban Politics: Past, Present, and Future with Harlan Hahn; Readings in Urban Politics with Harlan Hahn; and Managing Human Resources: A Challenge to Urban Government. He was the founding co-editor of Administration and Society and served on numerous editorial boards in public administration and public policy.

His scholarship also included nine works that had a direct practical impact on public management such as his influential publications The Quiet Crisis of the Civil Service: The Federal Personnel System at the Crossroads and Attracting New Staff and Retaining Capability During a Period of Declining Manpower Ceilings for the prestigious National Academy of Public Administration. His scholarship in the management of law enforcement agencies is also well known in the criminal justice field. His publica. tions in this field include Strategic Management for Law Enforcement Agencies (for the 
National Institute of Justice in 1985), Cutback Monogement in Criminal Justice (COauthored 1981. National Institute of Justice), and Managing the Pressures of Inflation in Criminal Justice (co-authored 1979. National Institute of Law Enforcement and Criminal Justice).

His most recent publication, "Reagan and the Bureaucracy: The Bequest, the Promise and the Legacy" with Peter Benda in Charles $O$. Jones' The Reagan Legacy, was similar to his most cited articles and chapters: insightful, stimulating, and often with major practical application for public officials. Charlie had the rare ability to combine the world of careful scholarship with the practical needs of public management; consequently he was widely known and respected in both academia and government.

Charlie Levine was a Member of the Boards of Trustees of the National Academy of Public Administration and of the $\mathrm{Pi}$ Alpha Alpha National Honor Society. He was an active member of the American Society of Public Administration, serving as program chair for the 1983 annual meeting and chair of six major committees of the organization. Charlie also belonged to the American Political Science Association, was a Council Member of the National Capital Area Political Science Association, member of several committees of the $\mathrm{Na}$ tional Association of Schools of Public Affairs and Administration, including its Executive Committee. He chaired panels and presented papers at over one hundred professional meetings and was a popular lecturer at many state, local and federal government agencies. A much sought after speaker at colleges and universities, he had been invited as a visiting lecturer by over thirty institutions of higher learning throughout the world.

In 1987 Charlie was awarded the Marshall E. Dimock Award by ASPA. He was also given the first Distinguished Research Award in 1986 by NASPAA and ASPA combined. He was presented the Special Recognition Award for Scholarship by the Classification and Compensation Society for his work on civil service reform. In 1979 ASPA gave him the William E. Mosher Award for his research. Charlie was also a member of $\mathrm{Pi}$ Sigma Alpha (political science honorary).

Everyone who knew him says that Charlie Levine was one of the most dedicated teachers and friends they have ever known. He turned colleagues into friends, students into scholars and talented public servants. Many of his former students from Michigan State University, Syracuse University, Cornell University, University of Maryland, University of Kansas, University of Virginia, and The American University are now prominent scholars at leading universities in this country, top public officials in state, local and federal government, key congressional staff, and wellknown scholars in research institutions throughout this country. Charlie was always a scholar-teacher-activist whether in a university or when he was a senior staff member with the Brookings Institution. Senior Specialist in American $\mathrm{Na}$ tional Government at the Congressional Research Service of the Library of Congress, or more recently as Deputy Director of the National Commission on the Public Service. His "students" in those roles included U.S. Senators, members of the House of Representatives, congressional staff, business leaders, public managers everywhere in state, local and federal government. Charlie Levine will long be remembered and missed by all of the scholars, students, public officials, and friends whose lives he has touched as a selfless mentor, generous friend and creative scholar.

From 1981 to 1983 Charlie was the Edwin 0 . Stene Distinguished Professor of Public Administration at the University of Kansas. When Charlie joined the faculty of the School of Public Affairs at The American University as the university's first Distinguished Professor in September 1987, it was like a member of the family coming home. He had known most of the faculty well and had helped to give the school advice over the years on curriculum and personnel. Charlie served as the first series editor of Government and Public Administration at The American University.

Charlie was a distinguished scholarteacher dedicated to improving public management, always a generous colleague and friend with a wonderful sense of humor. Above all Charlie knew where his 
strength came from, his wife Elaine and son Jordan. Charles always knew that the love, attention, and advice of Elaine and the joy of Jordie helped him remember what was important in life as he produced his legacy of scholarship, students, and friends. Memorial contributions from friends and colleagues may be made to the Charles H. Levine Memorial Fund, McLean School, 8224 Lochinver Lane, Potomac, MD 20854.

James $A$. Thurber and Bernard $H$. Ross The American University

\section{Gregory M. Luebbert}

Gregory M. Luebbert, assistant professor of political science at the University of California at Berkeley, died in a tragic boating accident in Idaho on May 24, 1988. Greg, aged 32, was an expert canoeist, known nationally for his daring and expertise.

Greg completed his B.A. at Lewis and Clark College in 1977. He received his Ph.D. in 1983 from Stanford University, after beginning his teaching career at Berkeley in 1982. During the academic year 1982-83, he was on leave from Berkeley and spent the year in the Netherlands under the auspices of the National Science Foundation.

A rising young star in the field of comparative politics, Greg completed several articles and a path-breaking book entitled Comparative Democracy: Policymaking and Governing Coalitions in Europe and Israel, in 1986. Shortly before his death, he had nearly completed another book, Social Foundations of Political Order in Inter-War Europe. Recipient of numerous awards and fellowships, during 1987-88, he was a Hoover National Fellow and holder of a Fulbright and German Marshall fellowship.

Fluent in over seven languages, Greg's work reflects deep historical and theoretical understanding of the politics of several countries. He exemplified the true comparative politics scholar, combining careful research skills with immense analytical sophistication.
As a teacher, Greg was highly admired and proved a great inspiration to dedicated graduate students. He guided them by example and by his insight and suggestions on how to tackle difficult problems. Greg always prodded his students to give the best of themselves.

For his many friends, colleagues, and students, Greg's untimely death at a time when his accomplishments were growing so rapidly, is a severe blow. The only solace is that those of us who knew him personally were fortunate to have been exposed to his brilliance and humor. His ideas and example will continue to inspire his many admirers.

A Gregory M. Luebbert Memorial Fellowship for graduate students in Greg's department has been established. Donations, made to the Regents of the University of California, can be mailed to the Department of Political Science, University of California, Berkeley, CA 94720 (c/o Professor Austin Ranney, Chairman).

Vinod K. Aggarwal
Giuseppe Di Palma
University of California, Berkeley

Harvey C. Mansfield, Sr.

Harvey C. Mansfield, Sr., died at the age of 83 at his home in New York City, April 27, 1988, after several months of illness. At his death he was Ruggles Professor of Public Law and Government Emeritus at Columbia University, and had enjoyed a notable and diverse career in political science.

Harvey was born in Cambridge, Massachusetts, March 3. 1905, and lived as a boy in Washington, DC. After his junior year in high school he attended Deep Springs College, a tiny junior college in California which combined ranch work and study. From there he went to Cornell where he obtained A.B. and A.M. degrees in 1927 and 1928, majoring in government and history. He went immediately to Columbia where he studied one year and ultimately received his Ph.D. in 1932. He studied under such luminaries of the day as Robert 